\title{
Hemophagocytic lymphohistiocytosis with concurrent malarial infection
}

\author{
Dhileepan Selvarajan, ${ }^{1}$ Swethika Sundaravel, ${ }^{2}$ Sayee Sundar Alagusundaramoorthy, ${ }^{3}$ \\ Aasems Jacob ${ }^{3}$
}

${ }^{1}$ Department of Internal Medicine, Government Stanley Medical College, Chennai, Tamil Nadu, India

${ }^{2}$ Department of Internal Medicine, JFK Medical Center, Atlantis, Florida, USA

${ }^{3}$ Department of Internal Medicine, Monmouth Medical Center, Long Branch, New Jersey, USA

\section{Correspondence to}

Dr Aasems Jacob

aasemsj@gmail.com

Accepted 22 June 2017

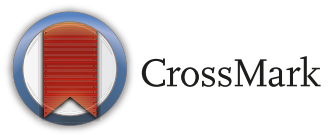

To cite: Selvarajan $D$, Sundaravel $\mathrm{S}$,

Alagusundaramoorthy SS, et al. BMJ Case Rep Published Online First: [please include Day Month Year]. doi:10.1136/bcr-2017221159

\section{DESCRIPTION}

A 24-year-old man with no significant medical history was presented to our emergency department with 5 days of fever with chills, rigors and abdominal pain. He had recently travelled to the Southern part of India. Physical examination showed a temperature of $101.2^{\circ} \mathrm{F}$, conjunctival pallor, left upper quadrant abdominal tenderness and moderate splenomegaly. Complete blood count revealed haemoglobin: $9.0 \mathrm{~g} / \mathrm{dL}$ (normal: $12-16 \mathrm{~g} / \mathrm{dL}$ ), white cell count (WBC): 2600/cu mm (normal: 4000-11 $000 /$ cumm) and platelets: $80 \quad 000 / \mathrm{cu} \mathrm{mm}$ (normal: $15000-450000 / \mathrm{cu} \mathrm{mm}$ ). Liver function test was remarkable for direct hyperbilirubinemia of $3 \mathrm{mg} / \mathrm{dL}$ (normal: $0-0.3 \mathrm{mg} / \mathrm{dL}$ ). Peripheral smear examination showed Plasmodium falciparum with a parasite density estimated to be 5 for every 100 WBCs on a thick peripheral smear. Severe malaria was confirmed and the patient started on a treatment with intravenous artesunate. After initiation of treatment, although his fever resolved, pancytopenia continued to worsen and the patient developed confusion, generalised petechiae, ecchymosis and spontaneous gum bleeding. Ferritin was elevated at $6463 \mathrm{ng} / \mathrm{mL}$ (normal:24$336 \mathrm{ng} / \mathrm{mL}$ ) and triglyceride at $282 \mathrm{mg} / \mathrm{dL}$ levels (normal: $<150 \mathrm{mg} / \mathrm{dL}$ ). An emergent bone marrow biopsy was performed, which revealed numerous hemophagocytes along with malarial gametocytes (figure 1). Satisfying six out of eight criteria as per hemophagocytic lymphohistiocytosis (HLH) 2004 guidelines,

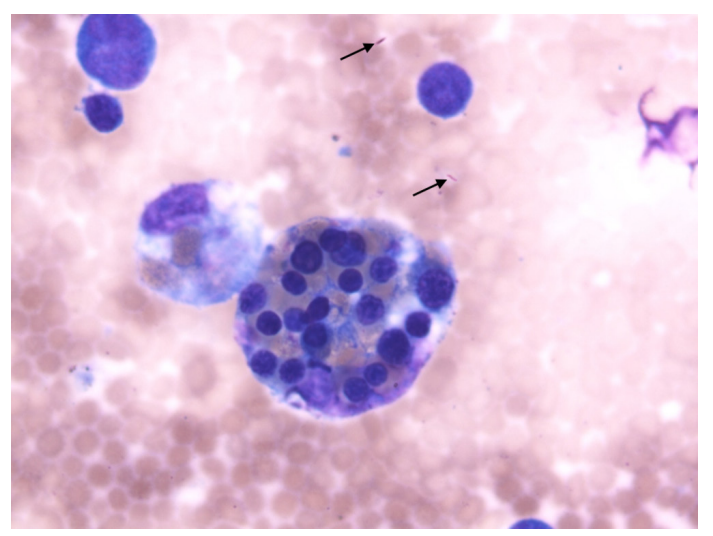

Figure 1 Bone marrow biopsy histology showing hemophagocytes with malarial gametocytes (shown with arrows).

\section{Learning points}

Hemophagocytic lymphohistiocytosis(HLH) is a rare immunological condition, characterised by widespread activation of the inflammatory system, mononuclear phagocytic system in the bone marrow and reticuloendothelial system. Primary $\mathrm{HLH}$ is caused by a genetic mutation while secondary HLH occurs in patients without a family history of mutations, in whom an evident triggering factor results in the disease.

- Common triggers for secondary HLH are viral infections (like EBV, CMV, HHV 8, dengue, HIV), bacterial infections (like Salmonella typhi, Mycobacterium tuberculosis), parasitic infections like malaria (both Vivax and Falciparum), ${ }^{3}$ malignancies (especially T-cell lymphomas), and other lymphoproliferative disorders and auto immune conditions including systemic lupus erythematosus, rheumatoid arthritis, Sjogren syndromeand dermatomyositis.

- Untreated HLH has a $90 \%$ mortality rate and persistence of pancytopenia, despite the treatment of malaria, should raise suspicion of HLH. Diagnosis is made with bone marrow biopsy and it is usually responsive to steroids.

hemophagocytic lymphohistiocytosis was diagnosed and the patient was started on intravenous dexamethasone $10 \mathrm{mg} / \mathrm{m}^{2}$ as per HLH-94 protocol. ${ }^{12}$ Etoposide was not initiated due to hepatic impairment. His blood cultures were negative and serological tests for Epstein-Barr virus (EBV), HIV, herpes simplex virus, hepatitis $\mathrm{B}$ and $\mathrm{E}$, Lyme disease, and cytomegalovirus (CMV) were also negative. He did not have any family history of HLH. The patient clinically improved after initiation of steroids and was transitioned to oral proguanil-atovaquone malaria completion therapy. He was discharged on day 10 on oral prednisone with dose tapered over 8 weeks as per protocol. On continued follow-up as outpatient after 2 weeks, it showed reduction in ferritin to $723 \mathrm{ng} / \mathrm{mL}$, normal blood counts and no parasitemia. There was no relapse of the disease.

Contributors DS was involved in the patient care and planning of manuscript. SS involved in the retrieval of images. SSA was involved 


\section{Images in...}

in the preparation of manuscript and patient care. AJ was involved in the preparation and editing of manuscript.

Competing interests None declared.

Patient consent Obtained.

Provenance and peer review Not commissioned; externally peer reviewed.

(c) BMJ Publishing Group Ltd (unless otherwise stated in the text of the article) 2017. All rights reserved. No commercial use is permitted unless otherwise expressly granted.

\section{REFERENCES}

1 Henter JI, Horne A, Arico M, et al. HLH-2004: diagnostic and therapeutic guidelines for hemophagocytic lymphohistiocytosis. Pediatr Blood Cancer 2006.

2 Henter Jl, Samuelsson-Horne A, Aricò M, et al. Treatment of hemophagocytic lymphohistiocytosis with HLH-94 immunochemotherapy and bone marrow transplantation. Blood 2002;100:2367-73.

3 Sung PS, Kim IH, Lee JH, et al. Hemophagocytic lymphohistiocytosis (HLH) Associated with plasmodium vivax infection: case Report and Review of the Literature. Chonnam Med J 2011;47:173-6.

Copyright 2017 BMJ Publishing Group. All rights reserved. For permission to reuse any of this content visit http://group.bmj.com/group/rights-licensing/permissions.

BMJ Case Report Fellows may re-use this article for personal use and teaching without any further permission.

Become a Fellow of BMJ Case Reports today and you can:

- Submit as many cases as you like

- Enjoy fast sympathetic peer review and rapid publication of accepted articles

- Access all the published articles

Re-use any of the published material for personal use and teaching without further permission

For information on Institutional Fellowships contact consortiasales@bmjgroup.com

Visit casereports.bmj.com for more articles like this and to become a Fellow 